\title{
Selection, training and validation process of a sensory panel for bread analysis: Influence of cultivar on the quality of breads made from common wheat and spelt wheat
}

\author{
María Jesús Callejo ，María-Eugenia Vargas-Kostiuk , Marta Rodríguez-Quijano
}

Keywords:

Wheat bread

Spelt wheat

Sensory analysis

Training protocol

\begin{abstract}
A B S T R A C T
A protocol of selection, training and validation of the members of the panel for bread sensory analysis is proposed to assess the influence of wheat cultivar on the sensory quality of bread. Three cultivars of bread wheat and two cultivars of spelt wheat organically-grown under the same edaphoclimatic conditions were milled and baked using the same milling and baking procedure. Through the use of triangle tests, differences were identified between the five breads. Significant differences were found between the spelt breads and those made with bread wheat for the attributes "crumb cell homogeneity" and "crumb elasticity". Significant differences were also found for the odor and flavor attributes, with the bread made with 'Espelta Navarra' being the most complex, from a sensory point of view. Based on the results of this study, we propose that sensory properties should be considered as breeding criteria for future work on genetic improvement.
\end{abstract}

\section{Introduction}

The suitability for bread-making of a particular variety of wheat is determined mainly by its genetic make-up. A wheat variety is more suitable for bread-making when the ability of its proteins to form the dimensional networks of gluten during kneading is greater. Environmental factors, such as nitrogen fertilization, water and temperature influence protein content. By contrast, protein quality is largely under genetic control.

Currently, about $95 \%$ of the wheat grown worldwide is alohexaploid bread wheat (Triticum aestivum ssp. vulgare L., genome AABBDD, $2 n=6 x=42$ ), while small amounts of other wheat species (einkorn, emmer, spelt) are still grown in some regions including Spain, Turkey, the Balkans and the Indian subcontinent.

Spelt wheat (T. aestivum ssp. spelta) is one of the husked hexaploid wheats that possesses the same genomes as bread wheat. Spelt has received interest in the last 20-30 years due to its high nutritional potential and suitability for low-input farming systems.
It has a lower yield and its long straw makes it susceptible to lodging (stem breakage), especially if too much nitrogen fertilizer is applied. Furthermore, as spelt is a hulled grain, a de-hulling step prior to milling is required. The recent renaissance of spelt as a niche product may be due to the perception that it is a 'healthier', more 'natural', or less 'over-bred' grain than modern wheat (Pruska-Kedzior et al., 2008).

Some authors have shown that spelt possesses a high nutritional potential due to its protein content and composition, as well as its lipids and crude fiber (Kohajdová and Karovicová, 2008). Spelt and common wheat gluten represent convenient natural models of gluten structures, differing significantly in their elementary building blocks, i.e. gliadins and glutenin subunits and Gli/Glu ratio. Spelt gluten tends to be more extensible and less elastic than modern wheat gluten, giving the typical, weaker spelt doughs (Kohajdová and Karovicová, 2008; Pruska-Kedzior et al., 2008), which are often too soft and sticky after kneading.

For this reason, baking procedures used for wheat flour breads cannot be applied directly to spelt flours. Differing experimental results on sensorial and instrumental analysis regarding spelt bread quality can be explained not only by differences in baking procedures, but also by the genetic material used (Cubadda and Marconi, 2002). The technological behavior of pure spelt cultivars or lines, for example, is radically different from that of varieties from spelt and wheat. 
Table 1

Sensory evaluation: methodology, objectives and material.

\begin{tabular}{|c|c|c|c|c|c|}
\hline Phase & Methodology & Objectives & \multicolumn{2}{|l|}{ Test code } & Material \\
\hline \multirow[t]{5}{*}{ Selection } & \multirow[t]{2}{*}{$\begin{array}{l}\text { Method of Investigating } \\
\text { sensitivity of taste } \\
\text { (ISO 3972, 2011) }\end{array}$} & Recognizing basic tastes & \multicolumn{2}{|l|}{ S1/Tastes } & $\begin{array}{l}\text { - } 50 \mathrm{ml} \text { plastic cups with solutions of } 5 \text { basic tastes. Crystallized } \\
\text { citric acid (monohydrated }) /(0.43 \mathrm{~g} / 1 \mathrm{l}) \text {, - Crystallized caffeine } \\
\text { (monohydrated }) /(0.195 \mathrm{~g} / 1),- \text { Anhydrous sodium } \\
\text { chloride } /(1.19 \mathrm{~g} / 1),- \text { Sucrose } /(5.76 \mathrm{~g} / \mathrm{l}),- \text { Anhydrous sodium } \\
\text { glutamate } /(0.595 \mathrm{~g} / 1) \text {, Neutral water }\end{array}$ \\
\hline & & $\begin{array}{l}\text { Familiarization with different } \\
\text { threshold types }\end{array}$ & \multicolumn{2}{|l|}{ S2/Tastes } & $\begin{array}{l}-50 \mathrm{ml} \text { of each sample for each dilution in plastic cups,- } \\
\text { Crystallized citric acid (monohydrated),- Crystallized caffeine } \\
\text { (monohydrated),- Anhydrous sodium chloride,- Sucrose, } \\
\text { Neutral water }\end{array}$ \\
\hline & $\begin{array}{l}\text { Initiation and training of } \\
\text { assessors in the detection } \\
\text { and recognition of odors } \\
\text { (ISO 5496, 2006) }\end{array}$ & Identification of bread odors & \multicolumn{2}{|l|}{ S3/Odors } & $\begin{array}{l}\text { Screw-top glass jars covered in aluminum foil with } 40 \mathrm{~g} \text { of } \\
\text { grated bread (Brand: Hacendado) to which were added different } \\
\text { concentrations of substances that allowed the identification of } \\
\text { the following aromas (per sample): shelled walnuts }(6 \mathrm{~g}) \text {,- } \\
\text { crushed aniseed }(0.05 \mathrm{~g}) \text {,- Skimmed milk powder (Brand: } \\
\text { Central Lechera Asturiana) }(15 \mathrm{~g}) \text { ), Licorice }(4 \mathrm{~g}) \text {,- Chopped and } \\
\text { crushed vanilla pods }(0.15 \mathrm{~g}) \text {,- Prunes (Brand: Hacendado) } \\
(2 \mathrm{~g}) \text { )- Compressed yeast (Brand: Lesaffre) }(5 \mathrm{~g}) \text {,- Grated } \\
\text { roasted crust bread }(4 \mathrm{~g}) \text {,- Honey (Honey sweets, Brand: } \\
\text { Pajuelo) ( } 2 \text { crushed sweets). }\end{array}$ \\
\hline & Ranking (ISO 8587, 2006) & $\begin{array}{l}\text { Ordering samples according to } \\
\text { specified criteria }\end{array}$ & \multicolumn{2}{|c|}{ S4/Crust darkness } & $\begin{array}{l}\text { Assessors presented with } 4 \text { loaves (par-baked, Brand: } \\
\text { Mercadona) that had been baked in a BOSCH domestic oven } \\
\text { for different periods of time: } 17 \mathrm{~min}, 22 \mathrm{~min}, 30 \mathrm{~min}, 40 \mathrm{~min}\end{array}$ \\
\hline & & & \multicolumn{2}{|c|}{$\begin{array}{l}\text { S5/Crumb firmness } \\
\text { S6/Crumb elasticity }\end{array}$} & $\begin{array}{l}\text { Five commercial breads were used that had previously been } \\
\text { evaluated for crumb firmness and elasticity with a } \\
\text { texturometer: Sourdough seed bread (Brand: Panflor),- } \\
\text { Round white loaf (Brand: Panflor),- Frozen pre-baked rustic } \\
\text { loaf (Brand: Hacendado), Rye loaf (Brand: La tahona de } \\
\text { Humilladero),- White tin loaf (Brand: Bimbo) }\end{array}$ \\
\hline \multirow[t]{8}{*}{ Training } & \multirow[t]{8}{*}{$\begin{array}{l}\text { Paired comparison test } \\
\text { (ISO 5495, 2005) }\end{array}$} & $\begin{array}{l}\text { Define vocabulary and acquire } \\
\text { familiarity with the definitions }\end{array}$ & \multicolumn{2}{|c|}{ T1/Crumb firmness } & $\begin{array}{l}\text { - Rye bread (Brand: La tahona de humilladero) (high crumb } \\
\text { firmness) and "spanish pistola" bread (low crumb firmness) }\end{array}$ \\
\hline & & and scale. & \multicolumn{2}{|c|}{ T2/Crumb elasticity } & $\begin{array}{l}\text { - Two samples of white tin loaf (Brand: Bimbo), one of which } \\
\text { (low elasticity) was kept in a refrigerator to enhance starch } \\
\text { retrogradation, which results in the loss of elasticity. }\end{array}$ \\
\hline & & & \multicolumn{2}{|c|}{ T3/Moistness bread crumb } & $\begin{array}{l}\text { - "Spanish candeal" bread, with low humidity and Artisan } \\
\text { style loaf (Brand: Panflor) with high humidity }\end{array}$ \\
\hline & & & \multicolumn{2}{|c|}{ T4/Cohesiveness } & $\begin{array}{l}\text { - Toasted bread (Brand: Diatosta Mini grill) (low } \\
\text { cohesiveness) and "spanish candeal" bread (high cohesiveness) }\end{array}$ \\
\hline & & & \multicolumn{2}{|c|}{ T5/Crumb cells number } & $\begin{array}{l}\text { "Spanish pistola" bread (low crumb cell number) and "spanish } \\
\text { candeal" bread (high crumb cell number) }\end{array}$ \\
\hline & & & \multicolumn{2}{|c|}{ T6/Crumb cells homogeneity } & $\begin{array}{l}\text { Ciabatta bread (low crumb cells homogeneity) and "spanish } \\
\text { candeal" bread (high crumb cells homogeneity) }\end{array}$ \\
\hline & & & \multicolumn{2}{|c|}{ T7/Lactic odor and flavor in the crumb } & $\begin{array}{l}\text { "Spanish pistola" bread (low lactic odor and flavor in the } \\
\text { crumb) and Lactic sourdough bread (high lactic odor and } \\
\text { flavor in the crumb) }\end{array}$ \\
\hline & & & \multicolumn{2}{|c|}{ T8/Acetic odor and flavor in the crumb } & $\begin{array}{l}\text { - "Spanish pistola" bread (low acetic odor and flavor in the } \\
\text { crumb) Acetic sourdough bread (high acetic odor and flavor } \\
\text { in the crumb) }\end{array}$ \\
\hline \multirow[t]{4}{*}{ Validation } & \multirow[t]{4}{*}{$\begin{array}{l}\text { Triangle test } \\
\text { (ISO } 4120,2004)\end{array}$} & \multirow{4}{*}{$\begin{array}{l}\text { Identify the discriminating capacity, } \\
\text { repeatability and reproducibility } \\
\text { for each panelist }\end{array}$} & $\begin{array}{l}\text { V1: A vs B } \\
\text { V2: A vs D }\end{array}$ & Acetic and lactic flavor & $\begin{array}{l}4 \text { different breads with the same ingredients varying the } \\
\text { quality of the sourdough and conditions of fermentation: }\end{array}$ \\
\hline & & & V3: C vs B & & $\begin{array}{l}\text { A: baker's yeast; B: baker's yeast and acetic sourdough; } \\
\text { C: baker's yeast and lactic sourdough; D: acetic sourdough }\end{array}$ \\
\hline & & & V4: E vs F & Appearance and texture & 3 different breads made with the same protocol but with \\
\hline & & & V5: F vs G & attributes & different flours: E: wholemeal wheat bread; F: wholemeal \\
\hline
\end{tabular}




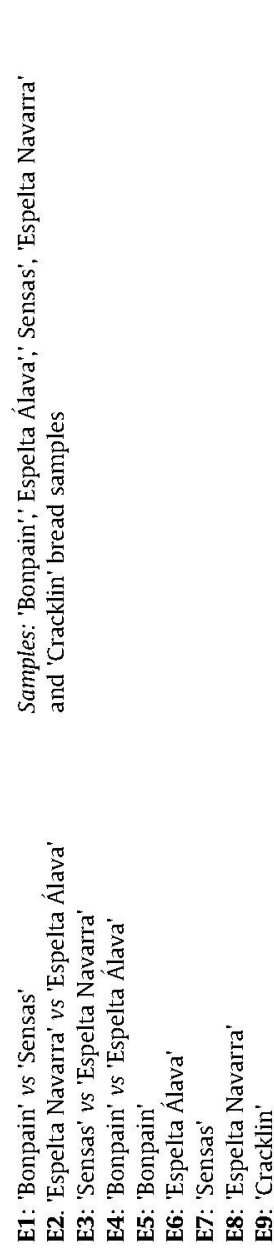

Spelt flour is also reputed to possess a unique flavor, with a very distinctive taste (Cubadda and Marconi, 2002). Some authors describe the breads as having a strong 'bread smell' (Bojnanská and Francaková, 2002). As the consumption of spelt food products is steadily increasing, there is a need to evaluate their sensory quality relative to normal wheat products.

The sensory quality of bread, an important component of total product quality, can be evaluated by analytical (objective) methods. This requires a well-trained testing panel and the use of specific and adequate attributes that are easily perceived and differentiated for different bread samples.

The aim of the present work was to investigate the influence of the wheat cultivar on the sensory quality of bread. The vegetal materials went through the same milling and dough-making processes, and the same bread-making protocol. A methodology is proposed for the selection, training and validation of a panel of judges for sensory analysis of five types of bread.

\section{Materials and methods}

\subsection{Plant material}

Breads were made with three commercial varieties of bread wheat (T. aestivum ssp. vulgare L.): 'Bonpain', 'Craklin' and 'Sensas', and two local varieties of spelt wheat ( $T$. aestivum ssp. spelta $L$.): 'Espelta Álava' and 'Espelta Navarra'. For the study, $25 \mathrm{~kg}$ of grain of each wheat variety, grown organically in 2010/2011 in Vitoria (Álava, Spain) ( $42^{\circ} 51^{\prime} \mathrm{N}, 2^{\circ} 40^{\prime} \mathrm{W}$ ), were kindly provided by the Diputación Foral de Álava.

\subsection{Baking procedure}

All wheat varieties were milled using a Ceramic Heger GmbH and Co. HG, Kv10 mill. After milling with the same procedure, the fractions extracted from each one of the five cultivars were mixed for $20 \mathrm{~min}$ in a Chopin flour blender at $48 \mathrm{rpm}$. Once mixed, the ash content (ICC 104/1, 2000), on a dry matter basis, was determined (1.14\% 'Bonpain', $0.78 \%$ 'Craklin', $1.04 \%$ 'Espelta Navarra', $1.06 \%$ 'Espelta Álava' and $1.10 \%$ 'Sensas') and the flours were used to make five different breads.

The recipe was as follows: $600 \mathrm{~g}$ flour, $500 \mathrm{~g}$ pregelatinized, 300 g yeasted sourdough, $18 \mathrm{~g}$ salt, $5 \mathrm{~g}$ commercial Lesaffre baker's yeast and an amount of water determined by consistograph data (320 g water for all breads except for 'Craklin', which required $270 \mathrm{~g}$ ). Pregelatinized was a mixture of $200 \mathrm{~g}$ of flour and $300 \mathrm{~g}$ of boiling water, prepared $24 \mathrm{~h}$ in advance and left to cool to $23{ }^{\circ} \mathrm{C}$ before adding to the mixer. This is a technique used for making spelt breads to avoid weak doughs, since spelt wheat gluten tends to be more extensible and less elastic than gluten of modern cultivars of wheat. Yeasted sourdough was made from $500 \mathrm{~g}$ flour, $250 \mathrm{~g}$ water and $2.5 \mathrm{~g}$ commercial Lesaffre baker's yeast, fermented at $24{ }^{\circ} \mathrm{C}$ for $24 \mathrm{~h}$ before adding to the mixer. Yeasted sourdough benefits lactic acid fermentation of fortuitous flora originating from flour (Katina et al. 2006).

For the baking process, all ingredients were mixed into a dough using a Teddy W5A Bear Varimixer. Mixing times were determined by the feel and appearance of the dough during mixing. Dough temperature was $24 \pm 1{ }^{\circ} \mathrm{C}$ after mixing. Resting time was $90 \mathrm{~min}$ at $25 \pm 1^{\circ} \mathrm{C}$ and a relative humidity of $80 \%$, during which the dough was folded. After resting in a Sveba Dahlen Smartbox Retarder/Prover, the dough was divided into $750 \mathrm{~g}$ loaves, molded by hand and proved in tins for $50 \mathrm{~min}$ at $25 \pm 1{ }^{\circ} \mathrm{C}$ and $80 \%$ relative humidity. The loaves were then baked in a Sveba Dahlen S200 oven. The oven temperature initially was $230^{\circ} \mathrm{C}$, but was immediately reduced to $180^{\circ} \mathrm{C}$ when the loaves were put in. At the beginning of the baking process, steam was added for $8 \mathrm{~s}$. The loaves were partially baked for $22 \mathrm{~min}$. After cooling 
for $2 \mathrm{~h}$ at room temperature, the parbaked bread was frozen at $-30^{\circ} \mathrm{C}$ with an air speed of $1.5 \mathrm{~m} \mathrm{~s}^{-1}$. After freezing, the parbaked bread was packed in polyethylene bags and stored in a freezer at $-18^{\circ} \mathrm{C}$. Before sensory evaluation, the samples were removed from the freezer, thawed at room temperature for $1 \mathrm{~h}$ and then put in the oven at $210^{\circ} \mathrm{C}$ to complete the baking process (about $16 \mathrm{~min}$ ). After removal from the oven, the samples were left to cool for $2 \mathrm{~h}$ at room temperature and then sliced ready for the sensory analysis.

\subsection{Sensory evaluation}

Sensory analysis was carried out in a sensory evaluation laboratory compliant with international standards (ISO 8589, 2007). In order to describe the sensory properties of the five types of bread, the sensory profiling method was applied (ISO13299, 2003). This method consisted of two phases, an initial phase to select, train and validate the assessors and a subsequent phase focusing on the evaluation of the samples.

\subsubsection{Tasting panel}

Eighteen adults (nine female and nine male) aged between 27 and 65 years took part in this study. They were selected, screened and recruited following international standards (ISO 8586, 2012). Fifteen of them were university faculty staff members, thirteen of which had previously received theoretical and practical training in sensory analysis and had experience in tasting different products such as bread, wine or cheese. The other five had not taken part in a panel before. The assessors received no remuneration for participating in the panel.

2.3.2. First phase: selection, training and validation of the assessors 2.3.2.1. Selection phase. Eighteen people took part in the selection phase and carried out the tests described in Table 1 . These tests can be summarized as follows:

1. Evaluating the assessors' sensitivity to tastes (ISO 3972, 2011). Selection criteria were established based on their ability to recognize the taste of thirteen solutions comprising five basic tastes at a time (S1, Table 1) and their concentration thresholds for different tastes (S2, Table 1).

2. Initiation and training of assessors in the detection and recognition of odors (ISO 5496, 2006). $40 \mathrm{~g}$ of grated bread were placed in a screw-top glass jar covered in aluminum foil, to which specific concentrations of different substances were added in order to test the assessors' detection of certain bread odors, as shown in Table 1 (S3, Table 1).

3. Ranking (ISO 8587, 2006). Ranking the samples according to the attributes "crust color" (S4, Table 1), "crumb firmness" (S5, Table 1) and "crumb elasticity" (S6, Table 1).

Once the results from this phase were analyzed, nine members were selected and trained.

2.3.2.2. Training of the nine selected members of the panel. Training took place over a period of four months with one session per week. Each assessor took part in a maximum of three tests per session with a maximum of four samples per test and a $15 \mathrm{~min}$ break between tests.

The aim of the basic training was to develop each member's sensory memory and the use of vocabulary and scales for describing breads. Sessions comprised two parts, with the first part consisting of a theoretical class in sensory analyses and bread attributes and the second part consisting of tests focused on the detection and recognition of smells, tastes, textures etc. Sensory attributes were classified based on four characteristics: odor (olfactory perception), appearance (visual perception), texture (tactile and oral texture) and flavor (oral and retronasal).

Paired comparison tests (ISO 5495, 2005) were used, which gave the assessors reference points for the following attributes:

Texture: crumb firmness (T1, Table 1); crumb elasticity (T2, Table 1): moistness bread crumb (T3, Table 1); cohesiveness (T4, Table 1).

Appearance: crumb cells number (T5, Table 1); crumb cells homogeneity (T6, Table 1).

Aroma and flavor: lactic odor and flavor of the crumb (T7, Table 1); acetic odor and flavor of the crumb (T8, Table 1).

As the training progressed, descriptive terms and the relevant reference standards were established through panel discussions. Attribute definitions were taken from Callejo (2011). The selected attributes of the sensory profile described the odor, appearance, texture and flavor (simultaneous perception of odor, taste and trigeminal nerve response). During this phase, the assessors became familiar with the scales used.

2.3.2.3. Panel validation. After 48 h of training, a study was carried out to assess the discriminating ability and repeatability for each panelist as well as the group as a whole through the use of Sensory Triangle tests (ISO 4120, 2004). Each panelist evaluated three bread samples presented to them in a random order.

A total of seven different breads were baked for the validation exercise. Four of them (V1, V2, V3, Table 1) were made with the same ingredients, varying the quality of the sourdough and conditions of fermentation in order to generate different values of the flavor attributes, lactic acid and acetic acid (Chavan and Chavan, 2011). In particular, the dough yield [DY = (amount of flour + amount of water $) \times 100 /$ amount of flour] of a sourdough will significantly influence its flavor profile. The firmer the sourdough (lower DY), the more acetic acid is produced and the less lactic acid. The other three breads (V4, V5, V6, Table 1) were made following the same protocol but using base flours of differing qualities: whole wheat flour, spelt wheat flour or rye flour.

\subsubsection{Second phase: evaluation of the samples}

Once the panel was trained and validated, the assessors carried out the sensory analysis of the five breads evaluated in this study.

2.3.3.1. Triangle tests. The first analysis was aimed to determine whether the assessors were able to distinguish between samples, and if so, identify differences between the five breads. This was done through Triangle tests (ISO 4120, 2004) (E1 to E4, Table 2). In order to generate the descriptive terms to be used in the Sensory

Table 2

Number of correct responses by the 9 assessors and level of significance in training and validation phase and in triangle tests.

\begin{tabular}{lcl}
\hline Test code & Correct responses & Level of significance \\
\hline \multicolumn{2}{l}{ Training and validation of the panel } & \\
V1 & 8 & $0.1 \%$ \\
V2 & 9 & $0.1 \%$ \\
V3 & 6 & $5.0 \%$ \\
V4 & 8 & $0.1 \%$ \\
V5 & 9 & $0.1 \%$ \\
V6 & 9 & $0.1 \%$ \\
Triangle tests & & \\
E1 & 7 & $1.0 \%$ \\
E2 & 9 & $0.1 \%$ \\
E3 & 9 & $0.1 \%$ \\
E4 & 9 & $0.1 \%$ \\
\hline
\end{tabular}

Abbreviations: V1 to V6: see Table 1. E1 to E4: see Table 1. 
Triangle test, the assessors were asked to list the attributes for which they had identified differences between the breads. The Triangle tests were repeated twice.

2.3.3.2. The sensory profiling method. This phase evaluated the 5 sample breads following international standards (ISO 6564, 1985; ISO 4121, 2003) (E5 to E9, Table 1). The intensity of each attribute was scored on an unstructured $10 \mathrm{~cm}$ straight line labeled "not noticeable" and "very strong" at the left and right end points, respectively. All samples were assessed in duplicate.

\subsubsection{Evaluation procedure}

Sample breads were evaluated $4 \mathrm{~h}$ after baking. For analysis, they were sliced $(15 \mathrm{~mm})$ on a Krups TR522 slicing machine and placed in plastic sample containers.

Once the panel organizer had given the judges oral instructions, the judges began the analysis with the olfactory phase. They had to open the packet containing the sample, bring the crumb close to the nose and smell the sample with long and strong inhalations at the same time as squeezing it gently twice, in order to release the aromatic compounds. Then, the same process was repeated with the crust.

After the olfactory phase, the following phases were carried out in the order: appearance phase, texture phase (by hand and in mouth) and flavor phase.

One full slice of bread was evaluated for each sample (including the crumb and the crust), which was presented to the assessors with a 3 digit code. Participants were asked not to smoke, eat or drink anything, except water, for $2 \mathrm{~h}$ before the sessions. Assessors evaluated the samples at 12:00 midday, always before lunch. In order to minimize the influence of serving order and carry-over; presentation orders were based on a Williams square cross-over design (Laureati et al., 2012) and were systematically varied by participant and by session.

\subsection{Statistical analysis}

The results of the Triangle tests were analyzed by comparing the total number of correct responses with the minimum number of responses required for statistical significance (ISO 4120, 2004).

Panel performance was evaluated by the analysis of variance (ANOVA) of sensory profile data. The significant effect of replicate, sample and the interactions: assessor $\times$ sample and assessor $\times$ repetition indicates the repeatability, discriminative ability and homogeneity of the panel (Jensen et al., 2010). Where the ANOVA revealed significant differences, a Duncan pairwise comparison of means was used to identify differences between samples. The data were analyzed using SAS statistical software (SAS institute, Inc., 1996).

\section{Results and discussion}

The results are presented in two parts. The first part contains the results of the selection and training of the assessors while the second part analyzes the results of the sensory analysis of the five breads studied.

\subsection{Selection phase}

The results of tests S1 and S2 (See codes in Table 1) show that 15 candidates correctly identified $67 \%$ of the different tastes. In test S3 (See code in Table 1), 10 of the candidates correctly identified $67 \%$ of the different odors. In the Ranking tests S4 and S5 (See codes in Table 1), 17 of the 18 candidates correctly ordered the samples, while in test S6 (See code in Table 1), 12 of them correctly ordered the samples. Based on these results, 9 ( 5 female and 4 male) of the 18 candidates were selected for the panel. It has not been possible to compare these results with other studies since no results of this phase have been published previously.

\subsection{Training and validation of the panel}

During the four month training period, the assessors acquired a common qualitative and quantitative frame of reference for the main attributes of the descriptive profile of bread. The validation phase comprised six triangle tests, the results of which are presented in Table 2 . The results were analyzed by comparing the total number of correct responses with the minimum number of responses required for statistical significance using statistical tables (ISO 4120, 2004). The success rate for all assessors was significantly high enough to validate them as members of the panel (Table 2). It was not possible to compare these results with other studies either since no results of this phase have been published previously.

\subsection{Analysis of differences between samples in the triangle tests}

Four Triangle tests were carried out (E1 to E 4, Table 2) in order to determine if the assessors were able to discriminate between samples. The assessors were asked to report the attributes for which they were able to identify differences between the breads, in order to select those which better allow to characterize the five sample breads. From this analysis, the attribute list used in the sensory profiling method was established. The results of the triangle tests are shown in Table 2.

\subsection{Sensory profiling of the breads}

The assessors' responses for each descriptor for the replicates of each sample were first analyzed separately by ANOVA. Fig. 1 shows a bread sliced photograph obtained from the five samples. The first analysis took the assessor (judge), replicate and the interaction of judge and replicate as the sources of variance, with the different sensory attributes as variables. This showed that the effect of replicate was not significant for any of the sensorial attributes, which indicated a high consistency of the members of the panel overall. The interaction of judge and replicate was significant only for one of the odor attributes ("lactic") and two flavor attributes ("sweetness" and "sourness"). These results highlight the reliability of the assessors.

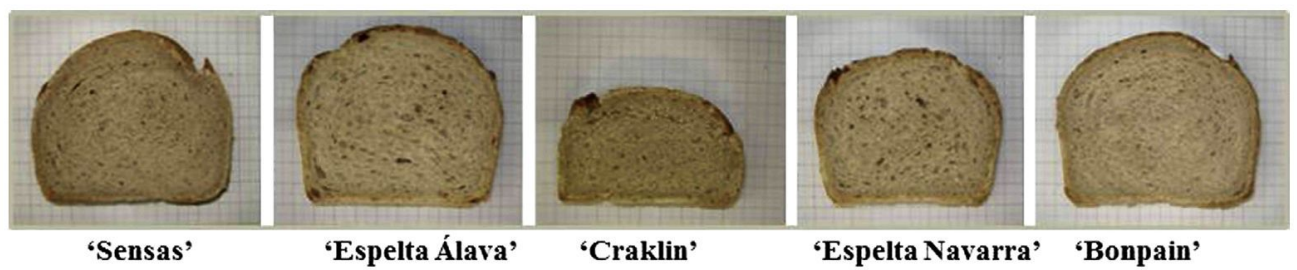

Fig. 1. Bread sliced photograph obtained from the five samples. 
The second ANOVA took the scores given by the nine assessors for the same bread (judges) as the sources of variance, with the different sensory attributes as variables (Table 3 ). The main factor (judges) was not significant for the attributes: "licorice" odor, "crust darkness", "crumb darkness", "crumb firmness", "sourness" flavor and "intensity of overall crumb flavor". For the other sensory descriptors, the effect of the judges was significant, thus indicating some inconsistencies between assessors. However, inconsistencies between judges are common in sensory evaluation and may be ascribed to a different use of the attribute scales (Laureatti et al., 2012).

The third ANOVA took the scores given by the assessors for each of the five bread samples (bread) as the sources of variance, with the different sensory attributes as variables (Table 3 ). The score for each bread type were significant for the attributes: "licorice" odor, "crust darkness", "crumb darkness", "crumb cells homogeneity", "crumb firmness" and "crumb elasticity". These results suggest that these attributes can be used to identify differences between the breads.

From the multiple range test (Duncan) (Table 4) for sensory attribute groups (odor, appearance, texture and flavor), it can be seen that assessor " 1 " gave the highest scores for all odor attributes while assessor " 3 " gave the lowest scores for most of them. However, nearly all of the attributes of the different breads were ranked by the judges in the same order. These results again highlight small inconsistencies between assessors, which can be attributed to a different use of the scales (Laureatti et al., 2012).

For the appearance attributes (Table 4), the assessors only had a very significant effect for "crumb cells number", indicating a consistent panel response for this group of attributes.

For the texture attributes, the assessors had no significant effect for "crumb firmness". For the other texture attributes, the results were similar to those of the odor attributes i.e. from the multiple range test (Table 4), some assessors consistently scored the attributes higher or lower than the other assessors. In this case, assessors " 3 " and " 9 " generally gave the highest scores while assessor " 2 " nearly always gave the lowest scores.

There was no significant effect (Table 4) of assessor for two of the five flavor attributes ("sourness" and "intensity of overall crumb flavor") but there was for the other three ("cereal", "sweetness" and "intensity of overall crust flavor"). There was no consistent ranking of this attribute group by the judges.

The analysis of the mean scores given by the assessors for each of the five breads with the multiple range test (Duncan) (Table 5) revealed significant differences for the tactile texture attributes and most of the appearance attributes. However, for the odor and flavor attributes, only "licorice" odor was significantly different between breads, being particularly scored in the 'Espelta Navarra' bread.

In a study on kama flour, a traditional Estonian food consisting of a newly-milled powder mixture of roasted barley, rye, wheat and pea flour, related the licorice odor to the presence of acetylpyrrole in the samples. The origin of this compound, and other pyrrole derivatives in bread, is related to the Maillard reactions that occur during bread baking and produce aromatic compounds in the crust. According to Cho and Peterson (2010), of all the pyrrole derivatives, the compound with the largest influence on aroma is 2-acetyl-1pyrroline, which is responsible for the toasted note of the crust. However, there are few references in the literature on the impact of pyrrole derivatives other than 2-acetyl-1-pyrroline in the crust. We also observed the presence of "toasted" odor in the crust of all five breads, with significant differences between the breads 'Craklin' and 'Espelta Navarra', which were scored lowest and highest for this attribute, respectively. Another novel aspect of our results is the identification of the attribute "licorice" odor in the crumb and not in the crust. This attribute has also been described in material of vegetable origin not submitted to thermal processes, by Vilanova 
Table 4

Duncan pairwise comparison of means for the 20 sensory descriptors given by the 9 judges.

\begin{tabular}{|c|c|c|c|c|c|c|c|c|c|c|c|c|c|c|c|c|c|c|c|c|}
\hline \multirow[t]{3}{*}{ Judge } & \multicolumn{7}{|c|}{ Odor attributes } & \multicolumn{4}{|c|}{ Appearance attributes } & \multicolumn{4}{|c|}{ Texture attributes } & \multicolumn{5}{|c|}{ Flavor attributes } \\
\hline & \multicolumn{6}{|c|}{ Crumb } & \multirow{2}{*}{$\frac{\text { Crust }}{\text { To }}$} & \multirow{2}{*}{$\frac{\text { Crust }}{D_{\text {st }}}$} & \multicolumn{3}{|c|}{ Crumb } & \multicolumn{2}{|c|}{ Tactile texture } & \multicolumn{2}{|c|}{ Oral texture } & \multicolumn{4}{|l|}{ Crumb } & \multirow{2}{*}{$\frac{\text { Crust }}{I^{\prime} C_{s t}}$} \\
\hline & Ye & $\mathrm{Lac}$ & Van & Nut & $\mathrm{P} 1$ & Lico & & & $\mathrm{D}_{\mathrm{md}}$ & $\mathrm{H}_{\mathrm{alv}}$ & $\mathrm{N}_{\text {alv }}$ & Fir & $\mathrm{El}$ & $\mathrm{M}_{\mathrm{st}}$ & Coh & Cer & So & Sw & $\mathrm{IOC}_{\mathrm{mb}}$ & \\
\hline (1) & $7.4^{\mathrm{a}}$ & $6.6^{\mathrm{a}}$ & $4.2^{\mathrm{a}}$ & $7.5^{\mathrm{a}}$ & $4.4^{\mathrm{a}}$ & $3.4^{\mathrm{a}}$ & $8.6^{\mathrm{a}}$ & $6.4^{\mathrm{a}}$ & $4.4^{\mathrm{b}}$ & $6.2^{\mathrm{a}}$ & $7.2^{\mathrm{ab}}$ & $7.2^{\mathrm{a}}$ & $3.4^{\mathrm{bc}}$ & $4.4^{\mathrm{c}}$ & $8.2^{\mathrm{a}}$ & $3.9^{\mathrm{d}}$ & $3.9^{\mathrm{a}}$ & $6.6^{\mathrm{ab}}$ & $5.4^{\mathrm{abc}}$ & $5.9^{\mathrm{a}}$ \\
\hline (2) & $2.1^{\mathrm{e}}$ & $2.0^{\mathrm{bcd}}$ & $1.6^{\mathrm{bc}}$ & $2.6^{\mathrm{bc}}$ & $0.7^{\mathrm{cd}}$ & $0.8^{\mathrm{a}}$ & $3.4^{\mathrm{c}}$ & $6.1^{\mathrm{a}}$ & $6.0^{\mathrm{ab}}$ & $4.7^{\mathrm{a}}$ & $4.7^{\mathrm{c}}$ & $5.4^{\mathrm{a}}$ & $3.8^{\mathrm{bc}}$ & $5.1^{\mathrm{bc}}$ & $4.6^{\mathrm{d}}$ & $4.0^{\mathrm{d}}$ & $1.8^{\mathrm{ab}}$ & $2.5^{\mathrm{cd}}$ & $4.1^{\mathrm{c}}$ & $3.6^{\mathrm{b}}$ \\
\hline (3) & $3.4^{\mathrm{cde}}$ & $2.2^{\mathrm{bcd}}$ & $0.1^{\mathrm{c}}$ & $1.3^{\mathrm{c}}$ & $0.3^{\mathrm{d}}$ & $0.9^{\mathrm{a}}$ & $3.3^{c}$ & $7.5^{\mathrm{a}}$ & $6.1^{\mathrm{ab}}$ & $6.0^{\mathrm{a}}$ & $7.5^{\mathrm{ab}}$ & $7.5^{\mathrm{a}}$ & $6.6^{\mathrm{a}}$ & $7.2^{\mathrm{a}}$ & $6.9^{\mathrm{abc}}$ & $4.4^{\mathrm{a}}$ & $0.6^{\mathrm{b}}$ & $2.1^{\mathrm{cd}}$ & $5.7^{\mathrm{abc}}$ & $6.4^{\mathrm{a}}$ \\
\hline (4) & $6.6^{\mathrm{ab}}$ & $2.6^{\mathrm{bc}}$ & $2.5^{\mathrm{ab}}$ & $3.1^{\mathrm{bc}}$ & $3.2^{\mathrm{abc}}$ & $1.6^{\mathrm{a}}$ & $6.8^{\mathrm{ab}}$ & $6.2^{\mathrm{a}}$ & $7.0^{\mathrm{a}}$ & $5.9^{\mathrm{a}}$ & $5.8^{\mathrm{bc}}$ & $6.5^{\mathrm{a}}$ & $3.2^{\mathrm{bc}}$ & $7^{\mathrm{a}}$ & $2.8^{\mathrm{e}}$ & $10^{\mathrm{a}}$ & $1.1^{\mathrm{b}}$ & $8.0^{\mathrm{a}}$ & $4.7^{\mathrm{bc}}$ & $4.2^{b}$ \\
\hline (5) & $6.7^{\mathrm{ab}}$ & $3.8^{\mathrm{b}}$ & $1.4^{\mathrm{bc}}$ & $3.8^{\mathrm{bc}}$ & $1.0^{\mathrm{bcd}}$ & $0.2^{\mathrm{a}}$ & $5.5^{\mathrm{bc}}$ & $7.4^{\mathrm{a}}$ & $6.6^{\mathrm{a}}$ & $6.2^{\mathrm{a}}$ & $4.3^{c}$ & $6.1^{\mathrm{a}}$ & $4.6^{\mathrm{ab}}$ & $6.4^{\mathrm{ab}}$ & $6.4^{\mathrm{bc}}$ & $6.4^{\mathrm{bc}}$ & $1.9^{\mathrm{ab}}$ & $2.4^{\mathrm{cd}}$ & $6.1^{\mathrm{abc}}$ & $5.8^{\mathrm{a}}$ \\
\hline (6) & $4.7^{\mathrm{c}}$ & $1.8^{\mathrm{cd}}$ & $2.7^{\mathrm{ab}}$ & $2.7^{\mathrm{bc}}$ & $0.7^{\mathrm{cd}}$ & $0.6^{a}$ & $5.5^{\mathrm{bc}}$ & $7.0^{\mathrm{a}}$ & $7.5^{\mathrm{a}}$ & $5.5^{\mathrm{a}}$ & $5.3^{c}$ & $7.7^{\mathrm{a}}$ & $2.0^{\mathrm{c}}$ & $6.8^{\mathrm{a}}$ & $6.4^{\mathrm{bc}}$ & $6.8^{\mathrm{b}}$ & $2.3^{\mathrm{ab}}$ & $5.4^{\mathrm{b}}$ & $6.6^{\mathrm{ab}}$ & $5.6^{\mathrm{a}}$ \\
\hline (7) & $5.1^{\mathrm{bc}}$ & $0.6^{\mathrm{d}}$ & $2.2^{\mathrm{b}}$ & $2.9 b c$ & $3.6^{\mathrm{ab}}$ & $3.0^{\mathrm{a}}$ & $5.9^{\mathrm{abc}}$ & $5.8^{\mathrm{a}}$ & $5.6^{\mathrm{ab}}$ & $5.9^{\mathrm{a}}$ & $6.0^{\mathrm{bc}}$ & $5.6^{\mathrm{a}}$ & $5.3^{\mathrm{ab}}$ & $6.3^{\mathrm{ab}}$ & $6.6^{\mathrm{bc}}$ & $5.2^{\mathrm{cd}}$ & $3.0^{\mathrm{ab}}$ & $2.1^{\mathrm{cd}}$ & $7.0^{\mathrm{a}}$ & $6.2^{\mathrm{a}}$ \\
\hline (8) & $4.1^{\mathrm{cd}}$ & $2.8^{b c}$ & $1.8^{\mathrm{bc}}$ & $3.8^{\mathrm{bc}}$ & $2.1^{\mathrm{abcd}}$ & $2.1^{\mathrm{a}}$ & $4.4^{\mathrm{bc}}$ & $7.0^{\mathrm{a}}$ & $5.5^{\mathrm{ab}}$ & $2.2^{\mathrm{b}}$ & $4.7^{c}$ & $6.3^{a}$ & $3.6^{\mathrm{bc}}$ & $6^{\mathrm{ab}}$ & $5.8^{\mathrm{dd}}$ & $6.5^{\mathrm{bc}}$ & $1.6^{\mathrm{ab}}$ & $1.2^{\mathrm{d}}$ & $5.4^{\mathrm{abc}}$ & $6.4^{\mathrm{a}}$ \\
\hline (9) & $2.6^{\text {de }}$ & $1.8^{\mathrm{cd}}$ & $3.1^{\mathrm{ab}}$ & $4.5^{\mathrm{b}}$ & $4.3^{\mathrm{a}}$ & $2.9^{\mathrm{a}}$ & $6.8^{\mathrm{ab}}$ & $7.1^{\mathrm{a}}$ & $6.3^{\mathrm{ab}}$ & $6.2^{\mathrm{a}}$ & $7.9^{\mathrm{a}}$ & $6.5^{\mathrm{a}}$ & $6.4^{\mathrm{a}}$ & $7.1^{\mathrm{a}}$ & $7.7^{\mathrm{ab}}$ & $6.3^{\mathrm{bc}}$ & $1.2^{\mathrm{b}}$ & $3.0^{\mathrm{c}}$ & $5.7^{\mathrm{abc}}$ & $6.6^{\mathrm{a}}$ \\
\hline
\end{tabular}

Means with the same letter are not significantly different (Duncan, $P<0.05$ ).

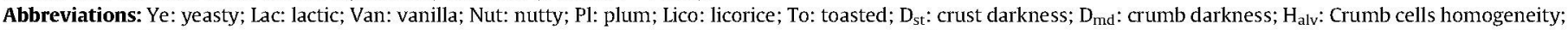

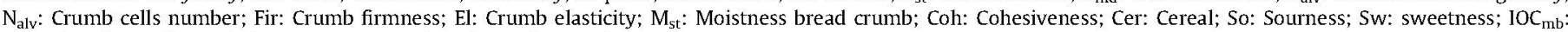
Intensity of overall crumb flavor; $10 C_{s t}$ : Intensity of overall crust flavor.

et al. (2009), who observed it in the Spanish grape cultivar 'Mencía'. This suggests that the presence of acetylpyrrole may also be related to the chemical composition of the vegetable material and not only as a result of the Maillard reactions.

No significant differences were found for the "yeasty" and "lactic" odors of the five breads. Similarly, no significant differences were found for the "plummy" and "nutty" odors for the breads made with bread wheat but were found between the two spelt breads. Taking into account all odor attributes, the bread 'Espelta Navarra' was scored the highest.

Since the breads were all made in exactly the same way, the significant differences found for the odor attributes must be due to different chemical compositions of the cultivars. Previous studies have postulated that wheat flour is an important source of bread odorants. Some compounds isolated in the wheat flour have also previously been identified as important contributors to the aroma of wheat bread crumbs (Grosch and Schieberle, 1997). More recently, Starr et al. (2013) also found differences in odor and flavor among 24 varieties of wheat during sensory evaluation of cooked wheat grain.

It is worth highlighting the high scores obtained by all breads for the attributes "intensity of overall crumb flavor" and "intensity of overall crust flavor". This is probably related to two factors: the high ash content of the breads and the use of yeast sourdoughs, as indicated by Czerny and Schieberle (2002), Katina et al. (2006) and Heenan et al. (2008). Outer layers of cereal kernel in wholemeal flours contain various phenolic compounds that can influence cereal flavor. On the other hand, sourdough fermentation is responsible for acidification, which has been shown to play a key role in the induction of proteolysis, which is responsible for the roast flavor, during sourdough fermentation.
There were no significant differences for "intensity of overall crumb flavor" between the breads made with bread wheat but there were significant differences between the two spelt breads. The bread made with 'Espelta Navarra' was scored the highest for this attribute and, together with the high scores for the odor attributes, allows us to conclude that this bread was the most complex from a sensory point of view. This bread was given the highest scores for the attributes $1-4$ and $19-20$.

No significant differences were found between the breads for the flavor attributes "cereal", "sourness" and "sweetness". However, it is worth noting the high scores given to all breads for cereal flavor. Previous studies have observed that breads produced with whole grains possess a typical grainy (cereal) odor (Heenan et al., 2008) and so breads with a high ash content, such as those in our study, might be expected to have a strong cereal flavor.

With regard to the appearance attributes, few differences were found between the scores for "crust darkness" and "crumb darkness" (Table 5). For the first of these, significant differences were only found for the 'Craklin' bread, which received the lowest scores. For "crumb darkness", the only significant differences found were for the 'Espelta Álava' bread, which received the lowest scores. No significant differences were found for the attribute "crumb cells number" but were found for "crumb cells homogeneity", with the spelt breads receiving significantly lower scores than the breads made with bread wheat.

For the texture attributes, the spelt breads had a greater "crumb elasticity" when compared with the breads made with bread wheat, with significant differences between the variety 'Espelta Álava' and the bread wheats. It should be emphasized that the 5 flours' protein content employed in this study ('Sensas': $9.24 \%$ 'Bonpain': 10.07\%, 'Espelta Álava': 9.10\% 'Espelta Navarra': 9.67\% and

Table 5

Duncan pairwise comparison of means for the 20 sensory descriptors for the five different bread samples.

\begin{tabular}{|c|c|c|c|c|c|c|c|c|c|c|c|c|c|c|c|c|c|c|c|c|}
\hline \multirow[t]{3}{*}{ Bread } & \multicolumn{7}{|c|}{ Odor attributes } & \multicolumn{4}{|c|}{ Appearance attributes } & \multicolumn{4}{|c|}{ Texture attributes } & \multicolumn{5}{|c|}{ Flavor attributes } \\
\hline & \multicolumn{6}{|c|}{ Crumb } & \multirow{2}{*}{$\frac{\text { Crust }}{\text { To }}$} & \multirow{2}{*}{$\frac{\text { Crust }}{D_{\text {st }}}$} & \multicolumn{3}{|c|}{ Crumb } & \multicolumn{2}{|c|}{ Tactile texture } & \multicolumn{2}{|c|}{ Oral texture } & \multicolumn{4}{|c|}{ Crumb } & \multirow{2}{*}{$\frac{\text { Crust }}{10 C_{s t}}$} \\
\hline & Ye & Lac & Van & Nut & $\mathrm{Pl}$ & Lico & & & $\mathrm{D}_{\mathrm{md}}$ & $\mathrm{H}_{\mathrm{alv}}$ & $\mathrm{N}_{\mathrm{alv}}$ & Fir & El & $\mathrm{M}_{\mathrm{st}}$ & Coh & Cer & So & Sw & $10 C_{\mathrm{mb}}$ & \\
\hline EA & $5.2^{\mathrm{a}}$ & $2.5^{\mathrm{a}}$ & $1.9^{\mathrm{ab}}$ & $2.4^{\mathrm{b}}$ & $1.0^{\mathrm{b}}$ & $0.7^{\mathrm{b}}$ & $6.1^{\mathrm{ab}}$ & $7.1^{\mathrm{a}}$ & $4.4^{\mathrm{b}}$ & $3.9^{\mathrm{c}}$ & $5.3^{\mathrm{a}}$ & $4.7^{\mathrm{C}}$ & $6.2^{\mathrm{a}}$ & $5.3^{\mathrm{b}}$ & $5.7^{\mathrm{a}}$ & $5.3^{\mathrm{a}}$ & $1.8^{\mathrm{a}}$ & $2.8^{\mathrm{a}}$ & $4.6^{\mathrm{b}}$ & $5.8^{\mathrm{a}}$ \\
\hline B & $4.9^{\mathrm{a}}$ & $2.7^{\mathrm{a}}$ & $2.5^{\mathrm{ab}}$ & $3.6^{\mathrm{ab}}$ & $2.2^{\mathrm{ab}}$ & $1.0^{\mathrm{b}}$ & $5.6^{\mathrm{ab}}$ & $7.1^{\mathrm{a}}$ & $7.1^{\mathrm{a}}$ & $5.9^{\mathrm{ab}}$ & $6.6^{\mathrm{a}}$ & $6.4^{\mathrm{b}}$ & $4.0^{\mathrm{bc}}$ & $6.4^{\mathrm{ab}}$ & $6.6^{\mathrm{a}}$ & $6.7^{\mathrm{a}}$ & $1.9^{\mathrm{a}}$ & $3.0^{\mathrm{a}}$ & $5.4^{\mathrm{ab}}$ & $5.5^{\mathrm{a}}$ \\
\hline Se & $4.9^{\mathrm{a}}$ & $3.3^{a}$ & $2.5^{\mathrm{ab}}$ & $3.3^{\mathrm{ab}}$ & $2.4^{\mathrm{ab}}$ & $1.2^{\mathrm{b}}$ & $4.7^{\mathrm{ab}}$ & $6.8^{\mathrm{a}}$ & $7.1^{\mathrm{a}}$ & $6.6^{\mathrm{a}}$ & $6.4^{\mathrm{a}}$ & $6.9^{\mathrm{b}}$ & $3.1^{\mathrm{c}}$ & $7.1^{\mathrm{a}}$ & $6.1^{\mathrm{a}}$ & $6.0^{\mathrm{a}}$ & $1.6^{\mathrm{a}}$ & $4.3^{a}$ & $5.8^{\mathrm{ab}}$ & $5.6^{\mathrm{a}}$ \\
\hline $\mathrm{Cr}$ & $4.6^{\mathrm{a}}$ & $2.5^{a}$ & $1.2^{\mathrm{b}}$ & $3.5^{\mathrm{ab}}$ & $1.6^{\mathrm{b}}$ & $0.4^{\mathrm{b}}$ & $4.4^{\mathrm{b}}$ & $4.9^{\mathrm{b}}$ & $6.2^{\mathrm{a}}$ & $6.4^{\mathrm{a}}$ & $6.3^{\mathrm{a}}$ & $8.5^{\mathrm{a}}$ & $2.9^{\mathrm{c}}$ & $6.4^{\mathrm{ab}}$ & $6.5^{\mathrm{a}}$ & $6.0^{\mathrm{a}}$ & $1.4^{\mathrm{a}}$ & $3.8^{\mathrm{a}}$ & $5.4^{\mathrm{ab}}$ & $5.3^{\mathrm{a}}$ \\
\hline EN & $4.0^{\mathrm{a}}$ & $2.3^{a}$ & $2.8^{\mathrm{a}}$ & $5.0^{\mathrm{a}}$ & $4.1^{\mathrm{a}}$ & $5.2^{\mathrm{a}}$ & $7.0^{\mathrm{a}}$ & $7.4^{\mathrm{a}}$ & $5.9^{\mathrm{a}}$ & $4.5^{b c}$ & $5.1^{\mathrm{a}}$ & $6.2^{\mathrm{b}}$ & $5.3^{\mathrm{ab}}$ & $6.2^{\mathrm{ab}}$ & $5.8^{\mathrm{a}}$ & $5.7^{\mathrm{a}}$ & $2.9^{\mathrm{a}}$ & $4.9^{\mathrm{a}}$ & $7.0^{\mathrm{a}}$ & $6.0^{\mathrm{a}}$ \\
\hline
\end{tabular}

Means with the same letter are not significantly different (Duncan, $P<0.05$ ).

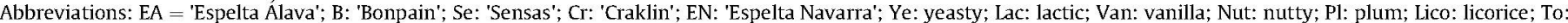

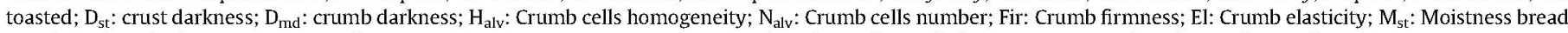
crumb; Coh: Cohesiveness; Cer: Cereal; So: Sourness; Sw: sweetness; $I_{\mathrm{Cmb}}$ : Intensity of overall crumb flavor; $\operatorname{IOC}_{\mathrm{st}}$ : Intensity of overall crust flavor. 
'Craklin': 6.08\%) cannot be associated to the differences at the textural parameters between spelt bread and wheat bread. However it could justify differences between the 3 wheat breads. Note that 'Craklin' is very different to the other two wheat breads. Crumb elasticity is traditionally associated with good baking performance (Khilberg et al., 2006). The spelt breads both received high scores for "crumb elasticity" and significantly lower scores for "crumb cell homogeneity", which could be related to the special rheological properties of the spelt doughs compared with those of bread wheat. Although some authors have found a high ratio of gliadin to glutenin subunits in spelt doughs, which is thought to be responsible for their low extensibility (Kohajdová and Karovicová, 2008; Pruska-Kedzior et al., 2008), it was precisely these breads in our study that had the greatest "crumb elasticity". This could be related to the process of pregelatinization, to which the flours were subjected before mixing and folding. These processes could also reduce the probability of the premature rupture of membranes between gas cells, thus allowing a prolonged and irregular oven rise, which could explain the low scores for "crumb cell homogeneity" received by the spelt breads.

\section{Conclusions}

Following a process of selection, training and validation of the members of the panel, a high reliability of assessors was obtained, although with some small inconsistencies attributed to a different use of the attribute scales. Through the use of triangle tests, differences were identified between five breads, each made with a single wheat variety, and the attributes that could be used to best characterize their sensory profiles were chosen.

The tactile texture attributes and most of the appearance attributes were significantly different between breads. Significant differences were found between the spelt breads and those made with bread wheat for the attributes "crumb cell homogeneity" and "crumb elasticity". Considering the odor and flavor attributes together, the bread made with 'Espelta Navarra' was the most complex, from a sensory point of view. Considering that all five wheat varieties were grown under the same edaphoclimatic conditions and were submitted to the same baking process, these differences have to be due to the cultivar used.

Until now, wheat sensory properties have not been systematically included as quality parameters in the selection of new wheat varieties, not only because it requires too large sample as well as because there is no standardized protocol for assessment and this work is an approach to this gap. Based on the results of this study, we propose that sensory properties should be considered as breeding criteria for future work on genetic improvement.

\section{Acknowledgments}

The authors would like to thank the Diputación Foral de Álava for their collaboration with this work. We are also grateful to the members of the testing panel and also to Manuel Flecha, master bread makers, who made the breads used to train the assessors. This work was supported by Grant No. AGL 2012-38345 from the Ministerio de Economía y Competitividad in Spain.

\section{References}

Bojnanská, T., Francáková, H., 2002. The use of spelt wheat (Triticum spelta L.) for baking applications. Rostl. Výroba 48, (4), 141-147.

Callejo, M.J., 2011. Present situation on the descriptive sensory analysis of bread. J. Sens. Stud. 26, 255-268.

Chavan, R.S., Chavan, S.R., 2011. Sourdough technology-A traditional way for wholesome foods: a Review. Compr. Rev. Food Sci. Food Saf. 10, 170-183.

Cho, 1.H., Peterson, D.G., 2010. Chemistry of bread aroma: a review. Food Sci. Biotechol. $19(3), 575-582$.

Cubadda, R., Marconi, E., 2002. Spelt wheat. In: Belton, P., Tayor, J. (Eds.), Pseudocereals and Less Common Cereals. Springer-Verlag, Berlin-Heidelberg, New York, pp. 153-173.

Czerny, M., Schieberle, P., 2002. Important aroma compounds in freshly ground wholemeal and white wheat flour. Identification and quantitative changes during sourdough fermentation. J. Agric. Food Chem. 50 (23), 6835-6840.

Grosch, W., Schieberle, P., 1997. Flavor of cereal products: a review. Cereal Chem. 74 (2), 91-97.

Heenan, S.P., Dufour, J., Hamid, N., Harvey, W., Delahunty, C.M., 2008. The sensory quality of fresh bread: descriptive attributes and consumer perceptions. Food Res. Int. 41 (10), 989-997.

ICC 104/1, 2000. Standard Methods. Determination of Ash in Cereal and Cerea Products. International Association for Cereal Chemistry, Vienna, Austria.

ISO 3972, 2011. Sensory Analysis. Method for Investigating Sensitivity of Taste. International Organization for Standardization, Geneva, Switzerland.

ISO 4120, 2004. Sensory Analysis. Triangular Test. International Organization for Standardization, Geneva, Switzerland.

ISO 4121, 2003. Sensory Analysis. Evaluation of Food Products by Methods Using Scales. International Organization for Standardization, Geneva, Switzerland.

ISO 5495, 2005. Sensory Analysis. Methodology. Paired Comparison Test. International Organization for Standardization, Geneva, Switzerland.

ISO 5496, 2006. Sensory Analysis. Initiation and Training of Assessors in the Detection and Recognition of Odours. International Organization for Standardization, Geneva, Switzerland.

ISO 6564, 1985. Sensory Analysis. Flavour Profile Methods. International Organization for Standardization, Geneva, Switzerland.

ISO 8586, 2012. Sensory Analysis. General Guiadance for the Selection, Training and Monitoring of Assessors. International Organization for Standardization, Geneva, Switzerland.

ISO 8587, 2006. Sensory Analysis. Ranking. International Organization of Standardization, Geneva, Switzerland.

ISO 8589, 2007. Sensory Analysis. General Guidance for the Design of Test Rooms International Organization for Standardization, Geneva, Switzerland.

ISO 13299, 2003. Sensory Analysis. General Guidance to Establish a Sensory Profile. International Organization for Standardization, Geneva, Switzerland.

Jensen, S. Oestdal, H., Thybo, A.K., 2010. Sensory profiling of changes in wheat and whole wheat bread during a prolonged period of storage. J. Sens. Stud. 25, 231-245.

Katina, K., Heiniö, R.L., Autio, K., Poutanen, K., 2006. Optimization of sourdough process for improved sensory profile and texture of wheat bread. LWT-Food Sci. Technol. 39 (10), 1189-1202.

Kihlberg, I., Öström, A., Johansson, L., Risvik, E., 2006. Sensory qualities of plain white pan bread: Inflence of farming system, year of harvest and baking technique. J. Cereal Sci. 43 (1), 15-30.

Kohajdová, Z., Karovičcová, J., 2008. Nutritional value and baking applications of spelt wheat. Acta Sci. Pol. Technol. Aliment. 7 (3), 5-14.

Laureati, M. Giussani, B., Pagliarini, E, 2012. Sensory and hedonic perception of gluten-free bread: comparison between celiac and non-celiac subjects. Food Res. Int. 46, 326-333.

Pruska-Kedzior, A., Kedzior, Z., Klockiewicz-Kaminska, E., 2008. Comparison of viscoelastic properties of gluten from spelt and common wheat. Eur. Food Res. Technol. 227, 199-207.

SAS Institute Inc, 1996. The SAS System for Windows, 6.12. ed. SAS Institute Inc. Cary, N.C. U.S.A.

Starr, G., Bredie, W.L.P., Hansen, A.s., 2013. Sensory properties of cooked grains from wheat species and varieties. J. Food Sci. 57, 295-303.

Vilanova, M., Masa, A., Tardaguilla, J., 2009. Evaluation of the aroma descriptors variability in Spanish grape cultivars by a quantitative descriptive analysis. Euphytica $165,383-389$. 